\title{
Transposition of Ambivalence towards Colonialism in Fine Arts: Intertext Analysis of the Battle of Sultan Agung against Jan Pieterzoon Coen (1974) Painting and the Sultan Agung: Throne, Struggle, Love (2018) Movie Poster
}

\author{
Mochamad Fauzie $^{1}$, Wirawan Sukarwo ${ }^{2}$, Ahmad Faiz Muntazori ${ }^{3}$ \\ \{mochamadfauzie@yahoo.co.id ${ }^{1}$, wirawansukarwo@gmail.com ${ }^{2}$, faiz.muntazori@gmail.com\}
}

Universitas Indraprasta PGRI, Jakarta, Indonesia ${ }^{123}$

\begin{abstract}
In a post-colonial society, cultural products it produced tend to contain a trauma of colonialism, indicated by an ambivalence towards its colonizer. The invasion of Sultan Agung to the VOC fort in Batavia in the $17^{\text {th }}$ century continues to be narrated in various forms of art. This study aims to identify visual and ambivalence transposition from S. Sudjojono's painting, "The Battle of Sultan Agung against Jan Pieterzoon Coen" (1974), to the movie poster of Sultan Agung (2018). The semiotic method of C. W. Morris was used to compare how the two works depict Sultan Agung's resistance to colonialism. Intertext and postcolonial theories were used as a tool of analysis. The results showed that there was a transposition of appearance and ambivalence from the painting to the movie poster. The visual transposition was characterized by the comparable composition of objects, while the ambivalence transposition was characterized by different attitude in depicting Sultan Agung's resistance to colonialists: the painting depicts Sultan Agung's resistance, but at the same time is cynical (out-group) against Sultan Agung; while the poster depicts the resistance of Sultan Agung, highlighting a sense of in-group, but at the same time is being trapped in a colonialistdesigned nativization.
\end{abstract}

Keywords: Sultan Agung, movie poster, painting, post-colonialism.

Transposisi Ambivalensi terhadap Kolonialisme dalam Seni Rupa: Analisis Interteks Lukisan Pertempuran Sultan Agung Melawan Jan Pieterzoon Coen (1974) dan Poster Film Sultan Agung: Tahta, Perjuangan, Cinta (2018)

\begin{abstract}
Abstrak. Dalam masyarakat bekas terjajah, produk budaya yang dihasilkan cenderung mengandung trauma penjajahan, ditandai dengan sikap mendua (ambivalen) terhadap penjajahnya. Penyerbuan Sultan Agung ke benteng VOC di Batavia pada abad ke-17 terus dinarasikan dalam pelbagai bentuk karya seni rupa. Penelitian ini bertujuan menemukan tanda-tanda transposisi rupa dan ambivalensi dari lukisan S. Sudjojono, "Pertempuran Sultan Agung melawan Jan Pieterzoon Coen" (1974), ke poster film Sultan Agung (2018). Metode semiotika C. W. Morris digunakan untuk membandingkan bagaimana kedua karya tersebut menggambarkan perlawanan Sultan Agung terhadap kolonialis. Teori interteks dan poskolonial digunakan sebagai pisau analisis. Hasil penelitian menunjukkan terjadinya transposisi rupa dan ambivalensi dari lukisan ke
\end{abstract}


poster film tersebut. Transposisi rupa ditandai dengan komposisi objek yang sangat mirip, sedangkan transposisi ambivalensi ditandai dengan perbedaan sikap dalam menggambarkan perlawanan Sultan Agung terhadap kolonialis: lukisan menggambarkan perlawanan Sultan Agung, tapi pada saat yang sama sinis (out-group) terhadap Sultan Agung; sedangkan poster menggambarkan perlawanan Sultan Agung, menonjolkan rasa in-group, tetapi pada saat yang sama terperangkap pada nativisasi yang didesain kolonialis.

Kata kunci: Sultan Agung, poster film, lukisan, poskolonialisme.

\section{Pendahuluan}

Dalam garis waktu Nusantara, 10 tahun pertama penjajahan Belanda ditandai oleh tiga peristiwa besar. Pertama, penaklukkan Belanda yang dipimpin oleh Jan Pieterzoon Coen atas Jayakarta pada 1619. Kedua, pembantaian rakyat Banda Neire dibawah komando orang yang sama, pada 1621. Dua peristiwa ini memicu peristiwa besar ketiga: penyerbuan tentara Sultan Agung (SA) ke benteng VOC di Batavia pada 1628 dan 1629. Tiga peristiwa inilah yang menandai titik-titik kontinum awal kolonialisme Belanda di Jawa dan sekitarnya, yang kemudian merembet ke seluruh Jawa dan Nusantara.

Penyerbuan Sultan Agung ke benteng VOC di Batavia merupakan perang terbesar di Pulau Jawa dalam abad ke-17, di mana SA mengerahkan 14 ribu tentara Mataram dari Yogyakarta, lewat darat dan laut. Sekalipun penyerangan ini gagal mengusir Belanda, tetapi tindakan SA menginspirasi perlawanan-perlawanan di Nusantara pada jaman-jaman sesudahnya, seperti perlawanan Sultan Ageng Tirtayasa di Kesultanan Banten, perlawanan Diponegoro (1825-1830), sampai perlawanan HOS Tjokroaminoto pada awal abad ke-20.

Sebagai pelaku sebuah peristiwa besar, Sultan Agung terus dinarasikan orang sepanjang jaman ke dalam pelbagai bentuk karya seni rupa. Di antara karya yang terkemuka adalah lukisan S. Sudjojono yang berjudul "Pertempuran Sultan Agung melawan Jan Pieterzoon Coen” yang dibuat pada 1973-1974, dan poster film Sultan Agung yang dibuat pada 2018.

Menurut Said [1], bangsa yang pernah dijajah mengalami trauma poskolonial yang berkepanjangan. Trauma tersebut ditandai dengan sifat ambivalen terhadap bangsa yang pernah menjajahnya. Sifat ini tumbuh karena bangsa terjajah terbiasa berada dalam ketegangan antara ketakutan dan keinginan untuk melawan. Sifat mendua tercermin dalam produk-produk budaya masyarakat poskolonial.

Edward Said telah mengawali kajian terhadap produk-produk budaya masyarakat terjajah yang dituangkan dalam bukunya, Orientalism (1978). Buku ini menjadi katalisator munculnya himpunan pengetahuan baru yang disebut Teori Poskolonial. Teori Said tentang ambivalens dipertajam Bhabha [2] dengan mengidentifikasinya ke dalam dua kategori: hibrid (memadu padan) dan mimikri (meniru atau menyerupai).

Ambivalensi sebagai bentuk trauma beroperasi di bawah sadar. Ia bisa bekerja pada karya-karya yang bahkan didesain sebagai ekspresi perlawanan terhadap penjajah. Sepintas bisa tampak sebagai perlawanan, padahal mungkin saja seraya melesapkan atau menyublimasi ketundukan atau keterperangkapan pada perilaku yang didesain penjajah.

Dalam perspektif Teori Interteks, setiap produk budaya dipandang sebagai teks. Teks merupakan mozaik kutipan dan transformasi atau transposisi teks dan konteks dari teks-teks yang mendahuluinya [3]. Teori ini meniscayakan adanya transposisi rupa. Dalam konteks 
karya rupa tersebut adalah produk masyarakat poskolonial, Teori Interteks mengimplikasikan adanya transposisi sifat mendua di dalamnya.

Penelitian ini hendak membongkar (decode) tanda transposisi rupa dan tanda ambivalensi dari lukisan S. Sudjojono, "Sultan Agung dan Jan Pieterzoon Coen" (1973), ke poster film "Sultan Agung, Tahta, Cinta dan Perjuangan" (2018). Cara yang ditempuh adalah dengan membandingkan dua karya tersebut dalam menggambarkan perlawanan Sultan Agung terhadap kolonialisme Belanda. Metode analisis akan menggunakan taksonomi semiotika CW Morris. Adapun wacana yang dipakai sebagai pendekatan adalah Teori Interteks dari Julia Kristeva dan Teori Poskolonial dari Edward Said/Homi Bhabha. Paradigma penelitian dengan demikian adalah konstruktivis. Pertanyaan penelitian adalah: Benarkah terjadi transposisi rupa dari lukisan ke poster? Bagaimana transposisi rupa itu terjadi? Mengapa transposisi tersebut terjadi?

Kajian untuk mengungkapkan ambivalensi merupakan upaya dekolonisasi mental yang seyogyanya digalakkan untuk menggugah kesadaran masyarakat Indonesia akan trauma poskolonial yang diidap secara kolektif dan turun-temurun. Kesadaran ini akan mendorong produksi budaya secara lebih percaya diri, dan merdeka dari bayang-bayang superioritas bekas penjajah.

\section{Metode}

Penelitian ini berjenis kualitatif. Subjek penelitian terdiri dari: 1) panil pertama lukisan "Pertempuran Sultan Agung melawan Jan Pieterzoon Coen" (1973-1974); 2) poster film "Sultan Agung, Tahta, Perjuangan, Cinta" (2018). Objek penelitian adalah tanda-tanda transposisi rupa dan transposisi ambivalensi dari lukisan ke poster. Teknik pengumpulan data dalam penelitian ini sebangun/identik dengan teknik analisis data, yakni memakai analisis semiotika CW Morris [4], yang terdiri dari tiga tingkatan: sintaktik, semantik, dan pragmatik. Wacana yang akan menjiwai semiosis (decoding), sebagaimana dituliskan di kolom pragmatik, adalah Poskolonialisme (Teori Poskolonial) dan Interteks. Unit analisis dengan demikian ada dua, yakni: analisis transposisi rupa, dan analisis transposisi ambivalensi.

Fakta ontologis subjek penelitian. Subjek pertama, adalah lukisan karya S. Soedjojono. Seni lukis adalah karya seni rupa berbentuk dua dimensi yang dibuat dengan cara membubuhkan cat di atas permukaan datar untuk mengungkapkan arti atau nilai subjektif [5]. Hasilnya disebut dengan lukisan. Sebagaimana kategorisasi dalam seni rupa, terdapat seni lukis tradisional dan seni lukis modern. Lukisan S. Soedjojono tergolong seni lukis modern, karena dibuat dengan sikap bathin menampakkan jiwa atau kepribadiannya ke dalam karya. Soedarso SP [6] menjelaskan, bahwa sikap bathin pelukis modern adalah sikap yang selalu ingin menciptakan yang baru dan lain daripada yang lain; satu syarat yang dituntut oleh seni modern yang menjadi ciri khasnya adalah "kreativitas". Lukisan "Pertempuran Sultan Agung melawan Jan Pieterzoon Coen" dibuat oleh S. Soedjojono pada 1973-1974 atas pesanan dari Gubernur Jakarta masa itu, Ali Sadikin, dalam rangka peresmian Museum Sejarah di Jakarta. Media yang digunakan adalah cat minyak dan kanvas. Dari segi ukuran, lukisan ini tergolong lukisan raksasa (giant painting), dengan panjang $10 \mathrm{~m}$ dan lebar 3 meter. Lukisan ini kini berada di Museum Fatahilah, Kompleks Kota Tua, Jakarta Utara.

Pelukisnya, S. Sudjojono, adalah seorang pelukis terkemuka dalam sejarah seni lukis Indonesia Baru (Modern). Bagi sebagian pelaku seni, ia dianggap sebagai pelopor seni rupa Indonesia Baru (Modern) karena aktivitasnya yang menonjol sebagai juru bicara PERSAGI, 
sebuah organisasi pelukis yang pada 1935 mencita-citakan tumbuhnya seni lukis yang tidak melayani selera turis, melainkan sepenuhnya berkarya sebagai jiwa yang merdeka.

Sudjojono terkenal dengan ucapan "seni adalah jiwo ketok". Dengan berkata demikian, seni dalam lukisan Sudjojono berada dalam pengertian sebagai "lambang sikap terhadap lingkungan dan sikap budaya penciptanya, tidak hanya sebagai individu, tetapi juga sebagai warga masyarakat dan sebagai bagian dari lingkup budaya di mana ia dibentuk dan dibesarkan" [5]. Konsep demikian sinkron dengan pernyataan Feldman [7], bahwa seni mengimplikasikan ideologi (worldview; sistem nilai; ideologi) yang dianut pembuatnya sebagai bagian dari komunitas, lingkungan atau habitat hidupnya.

Subjek penelitian yang kedua adalah poster film "Sultan Agung: Tahta, Cinta dan Perjuangan”. Filmnya sendiri disutradarai Hanung Bramantyo dan diluncurkan pada 2018. Terdapat tiga poster yang dibuat untuk film ini. Tulisan ini difokuskan pada poster yang versi gambar, sementara dua lainnya adalah versi [penggabungan; montage] foto.

Poster adalah iklan atau pengumuman yang diproduksi secara massal; poster adalah gambar pada selembar kertas berukuran besar yang digantung atau ditempel di dinding atau permukaan lain; poster merupakan alat untuk mengiklankan sesuatu, sebagai alat propaganda, dan protes, serta maksud-maksud lain untuk menyampaikan berbagai pesan [8].

Poster yang dibicarakan dalam penelitian ini adalah salah satu dari tiga poster yang dibuat untuk film" yang sama, "Sultan Agung: Tahta, Cinta, dan Perjuangan", karya Apriyanto. Poster ini hanya beredar di internet. Disebut versi gambar, sebab dibuat menyerupai gambar manual, sedang dua versi lain dibuat dengan mengkombinasikan foto. Sejatinya, poster ini dibuat secara digital.

Table 1. Kontinum Analisis Semiotika dari CW Morris

\begin{tabular}{llll}
\hline Level & \multicolumn{1}{c}{ Syntactic } & \multicolumn{1}{c}{ Semantic } & \multicolumn{1}{c}{ Pragmatic } \\
\hline Attribute & $\begin{array}{l}\text { Study of the structure of } \\
\text { signs }\end{array}$ & $\begin{array}{l}\text { Study of the meaning of } \\
\text { signs }\end{array}$ & $\begin{array}{l}\text { Study of the effect of } \\
\text { signs }\end{array}$ \\
\hline \multirow{3}{*}{ Element } & $\begin{array}{l}\text { Signifier/Signified } \\
\text { Syntagma/System } \\
\text { Denotation/Connotation } \\
\text { Metaphor/Metonimy }\end{array}$ & $\begin{array}{l}\text { Contextual } \\
\text { Denotation/Connotation }\end{array}$ & $\begin{array}{l}\text { Postcolonialism } \\
\text { Inteology/Myths }\end{array}$ \\
\hline
\end{tabular}

\section{Hasil dan Pembahasan}

\subsection{Syntactics Analysis}

Dalam Lukisan maupun poster: komposisi objek sangat mirip, ditandai dengan keseimbangan yang cenderung simetris dimana SA diposisikan di tengah bidang gambar. Warna dominan sepia/orange mendekati kecenderungan warna seni lukis Belanda abad ke-17. Pada lukisan, wajah SA digambarkan agak karikatural atau kurang proporsional, ukuran mata besar, tatapan datar, wajah secara keseluruhan tampak pucat dan sikapnya rileks. Pada poster, wajah SA digambarkan lebih proporsional, tatapannya lebih tajam, lebih fokus, dan sikapnya siaga, ditandai tangan kiri mencengkeram lutut.

Lukisan dan poster sama-sama mengelompokkan objek ke dalam tiga tahap: depan, tengah, dan belakang, menyerupai struktur lukisan pemandangan mahzab Den Haag. Perbedaannya, latar tengah maupun depan pada lukisan diisi kepala-kepala yang gelap dan melingkar sehingga menguatkan fokus, yakni kain motif parang yang dipakai SA. Sedangkan 
pada poster, komposisi objek lebih variatif, cahaya lebih menyebar dan ada aksentuasi cahaya pada wajah SA.

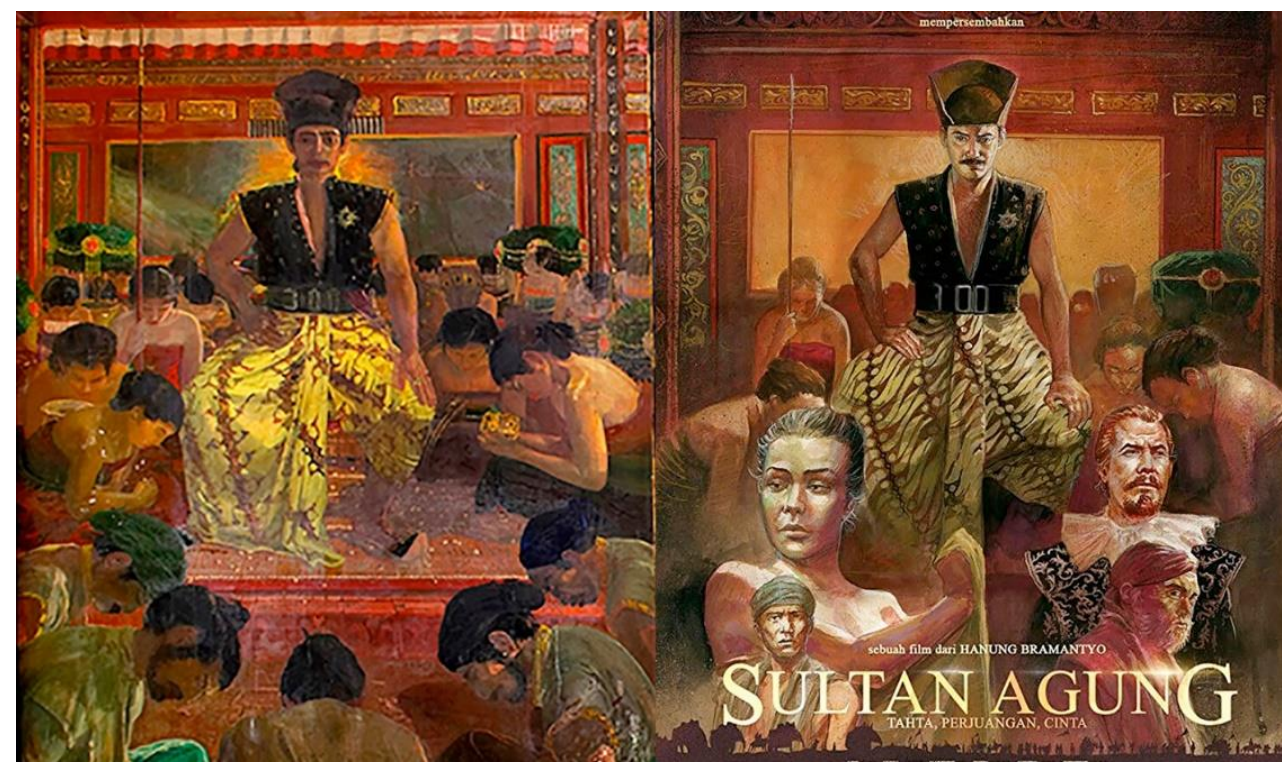

Gambar 1. Lukisan "Pertempuran Sultan Agung melawan Jan Pieterzoon Coen" (kiri) dan Poster Film "Sultan Agung: Tahta, Perjuangan, Cinta" (kanan), dan unsur-unsur di dalamnya yang mengalami transposisi

Table 2. Tanda-tanda transposisi rupa dari lukisan ke poster

\begin{tabular}{|c|c|c|c|}
\hline No. & Tanda visual & Denotasi & Konotasi \\
\hline 1. & Fokus & $\begin{array}{l}\text { Lukisan: kain motif parang } \\
\text { yang dikenakan SA. Poster: } \\
\text { wajah SA }\end{array}$ & $\begin{array}{l}\text { Transposisi metonimi SA dari } \\
\text { menonjolkan kelas sosial ke karakter }\end{array}$ \\
\hline 2. & $\begin{array}{l}\text { Komposisi } \\
\text { objek }\end{array}$ & $\begin{array}{lrr}\text { Komposisi } & \text { objek dalam } \\
\text { lukisan dan poster sangat } \\
\text { serupa, } & \text { membentuk } \\
\text { keseimbangan yang cenderung } \\
\text { simetris. }\end{array}$ & $\begin{array}{l}\text { Transposisi komposisi objek secara } \\
\text { nyaris meniru sepenuhnya }\end{array}$ \\
\hline 3. & Wajah SA & $\begin{array}{ll}\text { Lukisan: wajah } & \text { SA kurang } \\
\text { proporsional, } & \text { karikatural. } \\
\text { Poster: wajah } & \text { SA lebih } \\
\text { proporsional } & \end{array}$ & $\begin{array}{l}\text { Transposisi dari satire/sinis, ke lebih } \\
\text { menghargai }\end{array}$ \\
\hline 4. & $\begin{array}{l}\text { Sikap duduk } \\
\text { SA }\end{array}$ & $\begin{array}{l}\text { Lukisan: tangan } \\
\text { menelungkup di atas paha. } \\
\text { Poster: tangan } \\
\text { mencengkeram lutut }\end{array}$ & Transposisi dari rileks ke siaga \\
\hline 5. & $\begin{array}{l}\text { Sikap figur- } \\
\text { figur lain }\end{array}$ & $\begin{array}{l}\text { Lukisan: figur-figur yang } \\
\text { menunduk berlebihan. Poster: } \\
\text { figur-figur yang menunduk }\end{array}$ & $\begin{array}{l}\text { Transposisi dari ketundukan yang } \\
\text { ekstrim, kepada penghormatan }\end{array}$ \\
\hline
\end{tabular}




\begin{tabular}{lll}
\hline \multicolumn{3}{l}{ lebih tersamar } \\
\hline 6. Pencahayaan & $\begin{array}{l}\text { Lukisan secara umum gelap. } \\
\text { Poster secara umum lebih } \\
\text { terang }\end{array}$ & $\begin{array}{l}\text { Transposisi pencitraan pada SA, dari } \\
\text { kelam, suram, pesimis, dan } \\
\text { tersembunyi, kepada kecerahan, } \\
\text { optimistik, dan terbuka }\end{array}$ \\
\hline
\end{tabular}

\subsection{Semantics Analysis}

Bagian depan dan tengah lukisan dominan dengan kepala-kepala yang menunduk, mengonotasikan penghambaan yang ekstrim, pemujaan yang total, lebih takut tenimbang hormat, menguatkan mitos Raja sebagai "keturunan tuhan/dewa". SA digambarkan satusatunya orang yang menatap ke depan, yang mengonotasikan soliter, egois, otoriter. Kuning keemasan pada kain diposisikan sebagai fokus. Kain itu denotasi sandang, material, dengan motif parang yang menandakan kelas sosial tinggi. Latar belakang yang gelap, suram, berasosiasi pada masa lalu dan motif-motif tindakan yang tidak jelas. Penggambaran wajah dan tubuh SA secara tidak proporsional analog dengan sifat karikatur: satire/sinis. Tatapan datar dan sikap rileks SA, itu petanda sense of crisis yang nihil. Lukisan ini memotret Raja pada sisi-sisi yang kelam, suram, pesimistik, dan misterius.

Pada poster, orang-orang yang menunduk digambarkan lebih sedikit dan mengabur, ini menetralisir kesan penghambaan yang ekstrim. Pilihan warnanya secara umum lebih terang. Fokus diarahkan ke wajah SA dengan latar belakang yang bersih dan terang. Ini mengonotasikan optimisme, kewibawaan, kehormatan, kemuliaan, dan kegelisahan seorang pemimpin atas negerinya yang terjajah. Feodalisme di sini ditampilkan pada sisi-sisi yang cerah dan penuh harapan.

\subsection{Pragmatics Analysis dengan Interteks dan Poskolonialisme}

Ditemukan transposisi visual (peniruan dan perubahan) yang sangat kuat dari lukisan ke poster. Relasi interteks dalam struktur visual tersebut meliputi: komposisi objek, keseimbangan yang cenderung simetrik, komposisi warna. Sebagai seni murni, lukisan lebih bebas mengungkapkan ekspresi pembuatnya. Sedangkan pada poster, si pembuat terikat untuk harus mendukung fungsi pemasaran dan pesan dari pemilik modal. Ideologi apa yang beroperasi di baliknya, pada lukisan adalah ideologi ekspresionisme yang menjadi aliran pelukisnya. Kendatipun didahului riset, karya ekspresionis tidak akan kehilangan tekanan pada jiwa pelukisnya dan sistem nilai atau worldviewnya, termasuk dalam memandang kekuasaan raja atau feodalisme.

Lukisan kurang meyakinkan dalam menunjukkan keberpihakan pada SA. Sebagai karya bumiputera, lukisan lebih mengonotasikan sinis daripada in-group dengan SA. Lukisan sangat menonjolkan identitas kejawaan SA dan tidak menunjukkan identitas keislaman SA. Mungkin pelukisnya mengira ini adalah bentuk perlawanan, tapi sejatinya terperangkap dalam strategi nativisasi kolonialis terhadap bumiputera. Poster lebih menampakkan keberpihakan pada Raja sebagai representasi perlawanan terhadap penjajah. Feodalisme dipandang pada sisi-sisi yang positip dan optimistik. Sekalipun demikian, poster tidak memberi gambaran yang adil tentang adanya tanda-tanda identitas Islam. Poster lebih merayakan kejawaan tenimbang sekaligus 
keislaman. Ini adalah perlawanan yang ambivalens, sebab tanpa sadar mengikuti "skenario" kolonialis untuk memisahkan Islam dari kejawaan.

In record [9], Sultan SA attached the title Sunan to his name, which is usually only used by the wali (spreaders of Islam in Java). This signifies his great concern for Islam. On the other hand, the Dutch did not like the Sultanate of Mataram to be a strong Islamic empire. The contraction between them showed that the invasion of Sultan Agung to the VOC fortress in Batavia was fisabilillah war.

\section{Simpulan}

Kiranya dua pertanyaan penelitian telah terjawab. Pertama, adalah benar telah terjadi transposisi rupa dari lukisan "Pertempuran Sultan Agung Melawan Jan Pieterzoon Coen" ke poster film "Sultan Agung: Tahta, Perjuangan, dan Cinta". Kedua, transposisi tersebut terjadi karena perbedaan pandangan di antara masing-masing pembuat/pendukung karya. Pada lukisan, sifat kerakyatan pada diri pelukisnya (S. Soedjojono) melatari penggambaran SA secara satire atau sinis karena SA dipandang sebagai representasi pendukung sistem kelas sosial. Sedangkan pada poster, kepentingan pemilik modal (produser film) yang berasal dari kalangan bangsawan Jawa telah melatari keberpihakan pada SA. Tetapi baik lukisan maupun poster, keduanya menunjukkan sifat mendua dalam mengambarkan perlawanan SA terhadap penjajah: tampaknya seperti melawan penjajah, tetapi pada saat yang sama terperangkap dalam strategi nativisasi yang didesain kolonialis dengan menafikan faktor Islam sebagai motif perlawanan.

\section{Referensi}

[1] Said EW. Orientalism: Western Conceptions of the Orient, with a new Afterword. London: Penguin Books; 1995.

[2] Bhabha HK. The Location of Culture. London: Routledge; 1994.

[3] Kristeva J. Revolution in poetic language. New York: Columbia University Press; 1984.

[4] Morris CW. Foundation of the Teory of Signs. In: Neurath, Otto; Carnap, Rudolf; Morris CW, editor. Int. Encycl. Unified Sci. Volume I N, Chicago: The University of Chicago Pers; 1938.

[5] Sahman H. Mengenali Dunia Seni Rupa 1993.

[6] Sp S. Sejarah Perkembangan Seni Rupa Modern. Yogyakarta: Badan Penerbit ISI Yogyakarta; 2000.

[7] Feldman EB. Varieties of Visual Experience; Art as Image and Idea. New Jersey: Prentice Hall, Inc.; 1967.

[8] Kusrianto A. Pengantar Desain Komunikasi Visual. Yogyakarta: CV Andi; 2009.

[9] Bachtiar TA. Sejarah Nasional Indonesia 1. Bogor: Pascasarjana UIKA dan DDII; 2013. 